\title{
Combination of Hedgehog inhibitors and standard anticancer agents synergistically prevent osteosarcoma growth
}

\author{
YOSHINOBU SAITOH ${ }^{1 *}$, TAKAO SETOGUCHI ${ }^{2,3^{*}}$, MASAHITO NAGATA $^{1 *}$, ARISA TSURU $^{1}$, \\ SHUNSUKE NAKAMURA $^{1}$, SATOSHI NAGANO ${ }^{1}$, YASUHIRO ISHIDOU ${ }^{4}$, \\ HIROKO NAGAO-KITAMOTO ${ }^{1}$, MASAHIRO YOKOUCHI ${ }^{1}$, SHINGO MAEDA ${ }^{4}$, \\ AKIHIDE TANIMOTO $^{3,5}$, TATSUHIKO FURUKAWA ${ }^{3,6}$ and SETSURO KOMIYA ${ }^{1,3}$ \\ ${ }^{1}$ Department of Orthopaedic Surgery, ${ }^{2}$ The Near-Future Locomotor Organ Medicine Creation Course (Kusunoki Kai), \\ ${ }^{3}$ Center for the Research of Advanced Diagnosis and Therapy of Cancer, ${ }^{4}$ Department of Medical Joint Materials, \\ ${ }^{5}$ Department of Molecular and Cellular Pathology, ${ }^{6}$ Department of Molecular Oncology, Graduate School of Medical \\ and Dental Sciences, Kagoshima University, Kagoshima 890-8520, Japan
}

Received September 5, 2015; Accepted October 15, 2015

DOI: 10.3892/ijo.2015.3236

\begin{abstract}
High-dose chemotherapy and surgical intervention have improved long-term prognosis for non-metastatic osteosarcoma to 50-80\%. However, metastatic osteosarcoma exhibits resistance to standard chemotherapy. We and others have investigated the function of Hedgehog pathway in osteosarcoma. To apply our previous findings in clinical settings, we examined the effects of Hedgehog inhibitors including arsenic trioxide (ATO) and vismodegib combined with standard anticancer agents. We performed WST-1 assays using ATO, cisplatin (CDDP), ifosfamide (IFO), doxorubicin (DOX), and vismodegib. Combination-index (CI) was used to examine synergism using CalcuSyn software. Xenograft models were used to examine the synergism in vivo. WST-1 assays showed that 143B and Saos 2 cell proliferation was inhibited by ATO combined with CDDP, IFO, DOX, and vismodegib. Combination of ATO and CDDP, IFO, DOX or vismodegib was synergistic when the two compounds were used on proliferating 143B and Saos2 human osteosarcoma cells. An osteosarcoma xenograft model showed that treatment with ATO and CDDP, IFO, or vismodegib significantly prevented osteosarcoma growth in vivo compared with vehicle treatment.
\end{abstract}

Correspondence to: Dr Takao Setoguchi, The Near-Future Locomotor Organ Medicine Creation Course (Kusunoki Kai), Graduate School of Medical and Dental Sciences, Kagoshima University, 8-35-1 Sakuragaoka, Kagoshima 890-8520, Japan

E-mail: setoro@m2.kufm.kagoshima-u.ac.jp

*Contributed equally

Abbreviations: ATO, arsenic trioxide; PTCH1, patched1; SMO, smoothened; SUFU, suppressor of fused; GLI, glioma-associated oncogene homolog; FDA, Food and Drug Administration; APL, acute promyelocytic leukemia; ACTB, actin-beta

Key words: arsenic trioxide, osteosarcoma, Hedgehog, GLI2
Our findings indicate that combination of Hedgehog pathway inhibitors and standard FDA-approved anticancer agents with established safety for human use may be an attractive therapeutic method for treating osteosarcoma.

\section{Introduction}

Osteosarcoma is the most commonly diagnosed primary malignant tumor of the bone in children and adolescents $(1,2)$. High-dose chemotherapy and surgical intervention have improved long-term prognosis for non-metastatic disease to $\sim 50-80 \%$ (3). However, a high number of patients with osteosarcoma have a strong tendency of lung metastasis. Metastatic osteosarcoma exhibits resistance to standard chemotherapy (4).

To establish new chemotherapies to improve prognosis, many investigators have researched the molecular mechanisms of osteosarcoma growth and metastasis. We and others have investigated the function of the Hedgehog pathway in osteosarcoma. The Hedgehog pathway plays important roles in embryonic development and adult organ homeostasis and regeneration (5,6). Binding of Hedgehog ligands (sonic, Indian, and desert Hedgehog) to patched1 (PTCH1) promotes release of smoothened (SMO), which then leads to nuclear translocation and activation of GLI transcription factors (GLI1/-2/-3). GLI promotes transcription of target genes, including GLI1, HHIP, PTCH1, CYCLIN D, BCL2 and SNAIL (7). We and others reported that inhibition of smoothened (SMO) or GLI family zinc finger 2 (GLI2) prevents osteosarcoma growth and invasion in vitro and in vivo (8-12).

Arsenic trioxide (ATO) is a Food and Drug Administration (FDA)-approved reagent that is used to treat acute promyelocytic leukemia (APL) patients (13). Recently, ATO was proposed as a potentially useful inhibitor of Hedgehog-driven cancers including osteosarcoma $(11,14,15)$. Furthermore, an SMO inhibitor, vismodegib, has been approved for basal cell carcinoma treatment (16). To apply our previous findings in clinical settings, we examined the effects of Hedgehog inhibitors combined with standard anticancer agents. Our 

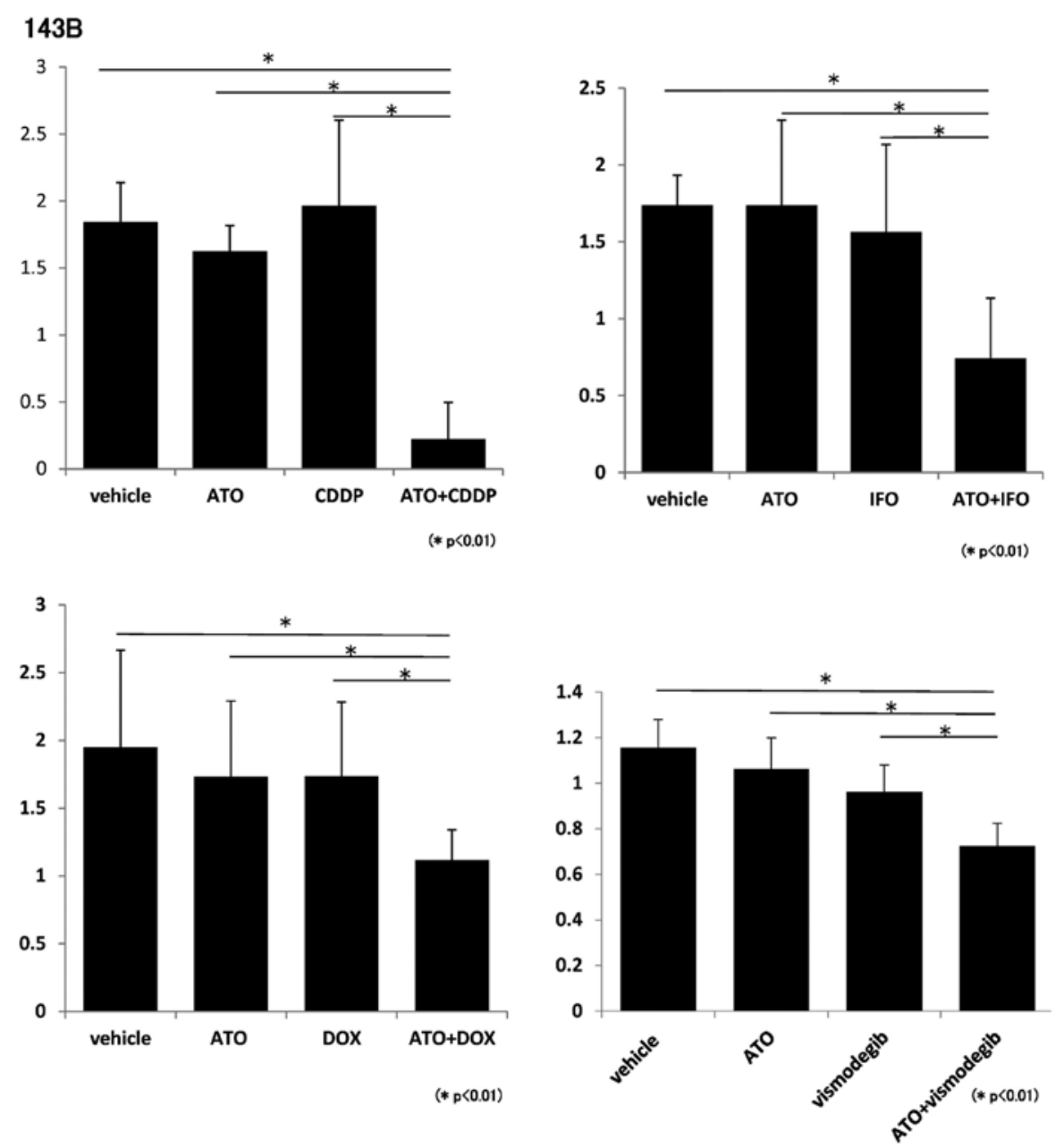

Figure 1. Combination of Hedgehog inhibitors and standard anticancer agents prevents proliferation of 143B cells. The proliferation of 143B cells treated with ATO or ATO in combination with CDDP, IFO, DOX, and vismodegib was analyzed by WST-1 assays. The experiment was performed in triplicate producing similar results. ${ }^{* *} \mathrm{P}<0.01$, Kruskal-Wallis test. Error bars represent the mean (SD).

findings showed that combination of Hedgehog inhibitors or combination of ATO and standard anticancer agents prevent osteosarcoma growth in vitro and in vivo.

\section{Materials and methods}

Cell lines and reagents. The human osteosarcoma cell lines 143B and Saos-2 were obtained from the American Type Culture Collection (ATCC; Manassas, VA, USA). Cell lines were cultured at $37^{\circ} \mathrm{C}$ in $5 \% \mathrm{CO}_{2}$. Cisplatin (CDDP), ifosfamide (IFO), and doxorubicin (DOX) were purchased from Sigma-Aldrich (St. Louis, USA), (Shionogi \& Co., Ltd., Osaka, Japan). ATO (Trisenox) was purchased from Nippon Shinyaku Co., Ltd. (Tokyo, Japan). Vismodegib (GDC-0449) was purchased from LC Laboratories (Woburn, MA, USA).

Analysis of cell viability. Cells were treated with ADM, CDDP, IFO, vismodegib and ATO. After $48 \mathrm{~h}$, cell viability was evaluated by colorimetric assay for mitochondrial dehydrogenase activity, as described previously (15) (WST-1; Roche, Basel, Switzerland).

Animal studies. Examinations of xenograft models were performed as previously reported $(9,15)$. For ATO and CDDP or ATO and IFO examinations, 143B cells $\left(1 \times 10^{6}\right)$ were suspended in $100 \mu \mathrm{l}$ of Matrigel (BD, NJ, USA). Suspensions of 143B osteosarcoma cells were subcutaneously inoculated in 5-week-old nude mice. For ATO and vismodegib examination, 143B cell $\left(1 \times 10^{6}\right)$ suspensions were inoculated into the left knee joint of 5-week-old nude mice. Tumor volume was calculated using the formula $\mathrm{LW}_{2} / 2(\mathrm{~L}$ and $\mathrm{W}$ indicating the length and width of tumors).

Xenograft models were randomly treated with ATO,CDDP, IFO, and vismodegib or an equal volume of vehicle as control. All animal experiments were performed in compliance with the guidelines of the Institute of Laboratory Animal Sciences, Graduate School of Medical and Dental Sciences, Kagoshima University. Every effort was employed to minimize both the number of animals used and animal pain.

Drug combination studies. Synergism after treatment with Hedgehog inhibitors and standard chemotherapeutic reagents was evaluated using CalcuSyn software (Biosoft, Ferguson, MO, USA), which is based on the median-effect principle applied by Chou and Talalay (17). From the fraction affected by the dose $(\mathrm{Fa})$ obtained from cell proliferation assays and the dose of drug (D), the software draws a dose effect curve and calculates the median-effect dose (Dm). Dm is same as 

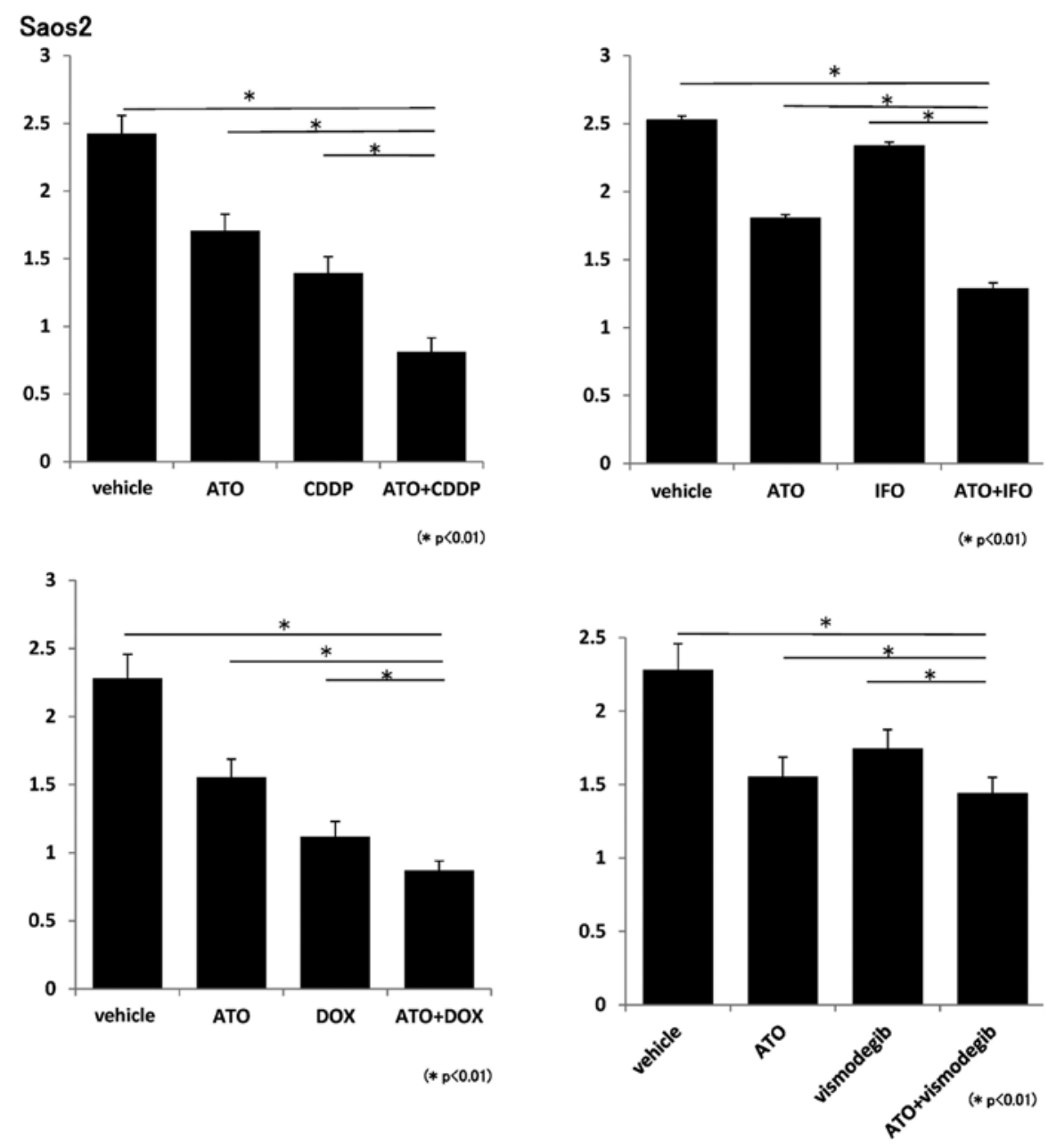

Figure 2. Combination of Hedgehog inhibitors and standard anticancer agents prevents proliferation of Saos 2 cells. The proliferation of Saos 2 cells treated with ATO or ATO in combination with CDDP, IFO, DOX, and vismodegib was analyzed by WST-1 assays. The experiment was performed in triplicate producing similar results. ${ }^{* *} \mathrm{P}<0.01$, Kruskal-Wallis test. Error bars represent mean (SD).

$\mathrm{ED}_{50}$. For each combinative dose effect, a combination-index (CI) was generated. The effects of the combinations were then transformed into and displayed as fraction-affected CI plots. If the data of single-agent and combination use is inputted, the software calculates the CI, which represents of the pharmacological interaction of two drugs. A CI value of 1 indicated an additive effect between the two agents, whereas a $\mathrm{CI}<1$ or $\mathrm{CI}>1$ indicated synergism or antagonism, respectively.

Statistical analysis. Statistical analyses were performed using Kruskal-Wallis tests with Excel Statistics 2012 and 2015 (SSRI, Tokyo, Japan). P-values of $<0.05$ were considered statistically significant.

\section{Results}

Combination of Hedgehog inhibitors and standard anticancer agents prevents proliferation of osteosarcoma cells. We evaluated the effect of anticancer agents including CDDP, IFO, and DOX, which are standard chemotherapeutic reagents for osteosarcoma patients in Japan (18). To determine whether ATO and standard anticancer agents prevent the proliferation of osteosarcoma cells, we performed WST-1 assays using ATO, CDDP, IFO, and DOX. WST-1 assays showed that prolifera- tion of 143B and Saos2 cells was inhibited by ATO and each standard chemotherapeutic reagent (Figs. 1 and 2). We next evaluated the effects of a combination of Hedgehog inhibitors using ATO and vismodegib. SMO inhibitor, vismodegib, was approved for the treatment of basal cell carcinoma (BCC) in 2012 and is undergoing clinical trials for metastatic cancer and advanced cancer $(16,19)$. WST-1 assays showed that 143B and Saos 2 cell proliferation was inhibited by ATO and vismodegib (Figs. 1 and 2). These findings showed that combination of ATO and chemotherapeutic reagents prevents proliferation of osteosarcoma cells in vitro.

Combination of Hedgehog inhibitors and standard chemotherapeutic reagents prevent osteosarcoma cell proliferation synergistically. On the basis of these findings, we evaluated whether combinations of ATO and standard chemotherapeutic reagents could be synergistic to prevent osteosarcoma growth. CIs were used to examine synergism after treatment with Hedgehog inhibitors and standard chemotherapeutic reagents (17). CI values and the degree of drug interaction were evaluated by CalcuSyn software. The effects of the combinations in 143B and Saos2 cells were then calculated and presented in a dose-effect plot (Figs. 3 and 4) and fraction-affected CI plots (Figs. 5 and 6). CIs of ATO with CDDP, IFO, or DOX at 


\section{B}
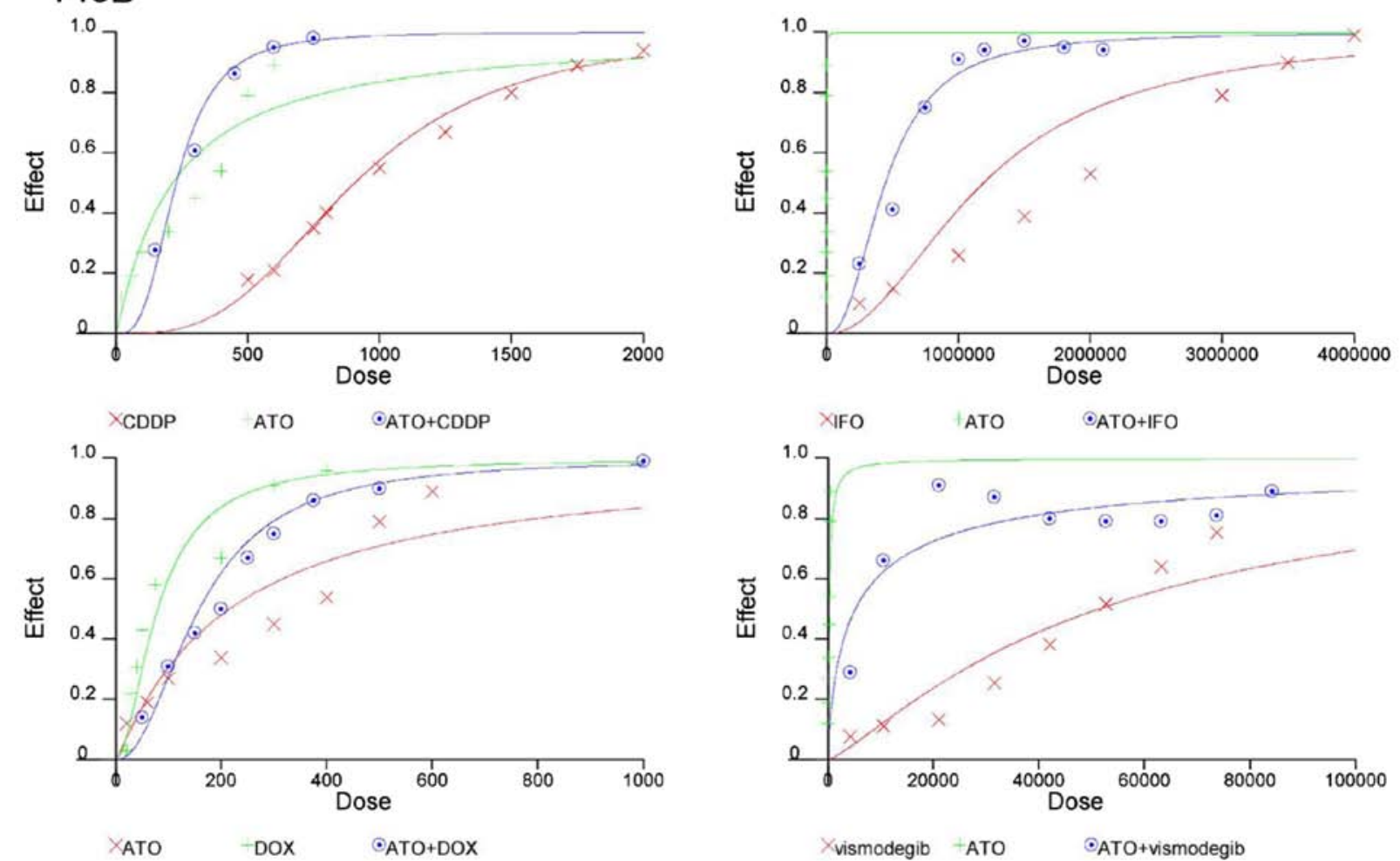

Figure 3. Dose-effect curves for cumulative doses of Hedgehog inhibitors and standard chemotherapeutic reagents. 143B cells were cultured in the presence of ATO, CDDP, IFO, DOX, and vismodegib or in combination. Cell viability was measured by WST-1 assays. Cell viability was measured by MTT after 48-h exposure. The dose-effect plot reflects the dose-effect relationships for ATO, CDDP, IFO, and vismodegib and respective combinations.
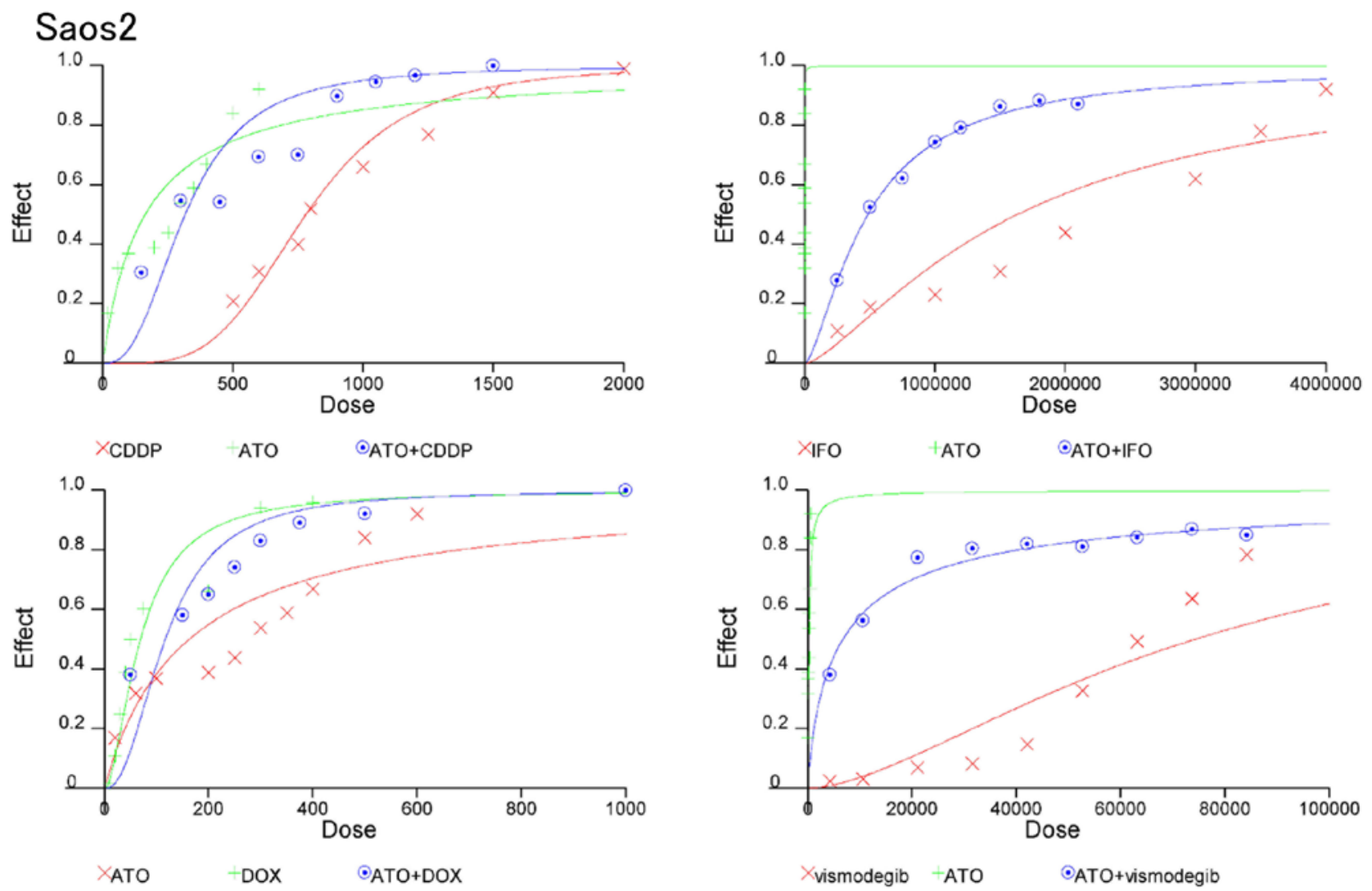

Figure 4. Dose-effect curves for cumulative doses of Hedgehog inhibitors and standard chemotherapeutic reagents. Saos 2 cells were cultured in the presence of ATO, CDDP, IFO, DOX, and vismodegib or in combination. Cell viability was measured by WST-1 assays. Cell viability was measured by MTT after 48-h exposure. The dose-effect plot reflects the dose-effect relationships for ATO, CDDP, IFO, and vismodegib and respective combinations. 


\section{$143 B$}

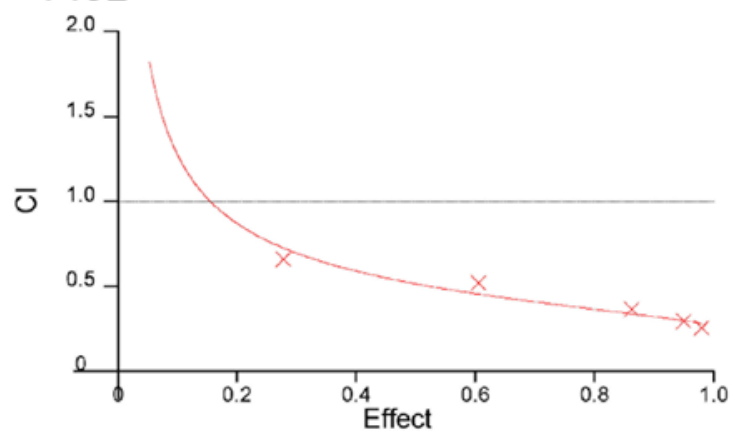

$X_{A T O}+C D D P$

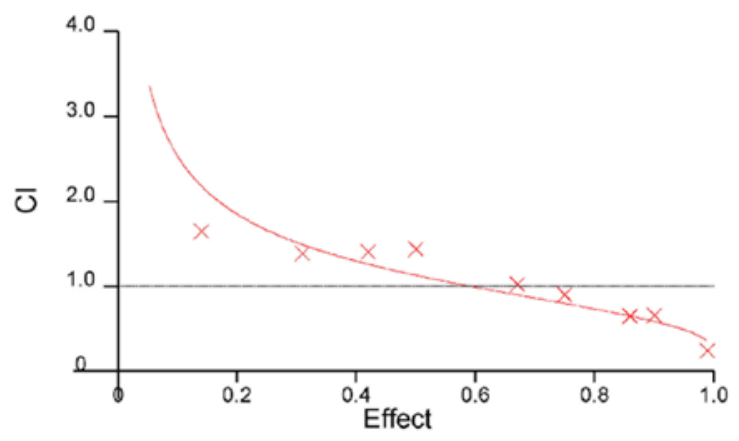

$\times$ ATO+DOX

$C l=1.0$

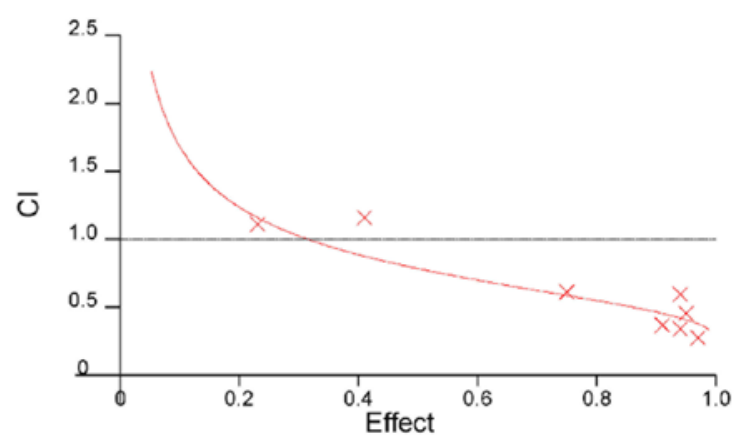

XATO+IFO

$\mathrm{Cl}=1.0$

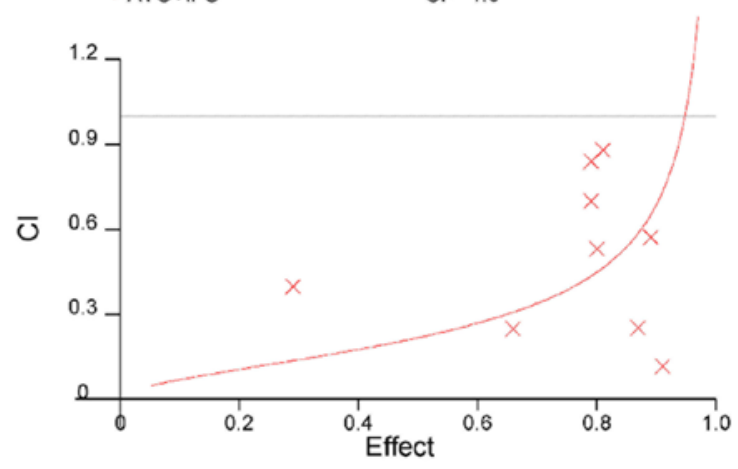

XATO+vismodegib

$\mathrm{Cl}=1.0$

Figure 5. Combination of Hedgehog inhibitors and standard chemotherapeutic reagents induces synergistic inhibition of the viability of human osteosarcoma cells. 143B cells were cultured in the presence of ATO, CDDP, IFO, DOX, and vismodegib or in combination. Cell viability was measured by WST-1 assays Cell viability was measured by MTT after 48-h exposure. Combination-index and fractions affected were plotted in combination with ATO and CDDP, IFO, DOX, or vismodegib.

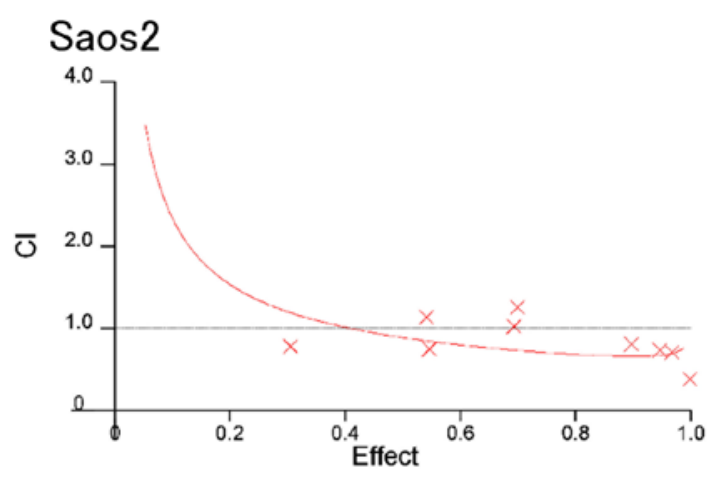

$X_{A T O}+C D D P$

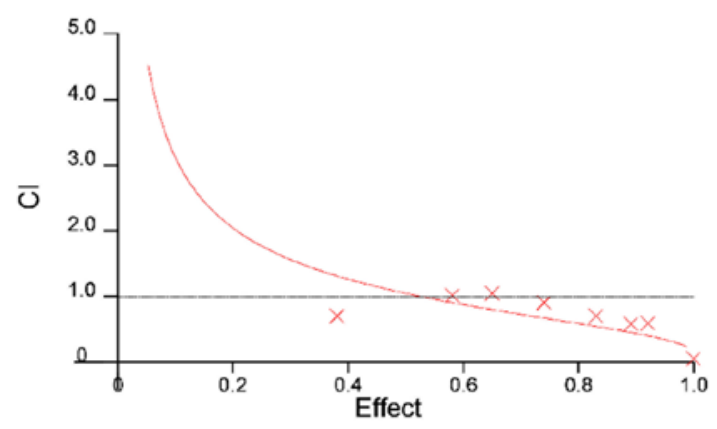

XATO+DOX

$$
\mathrm{Cl}=1.0
$$

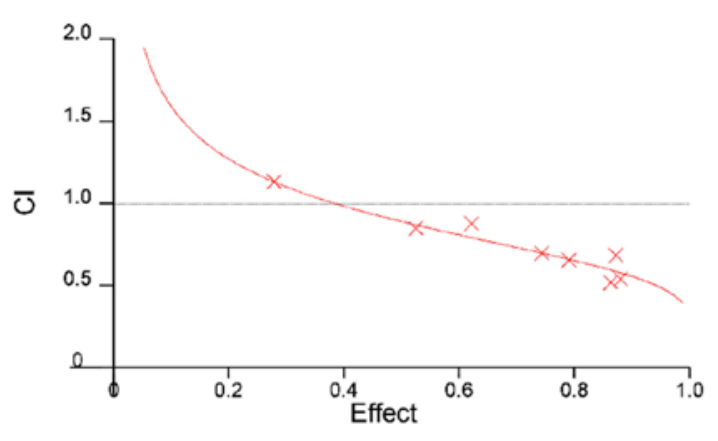

XATO+IFO

$\mathrm{Cl}=1.0$

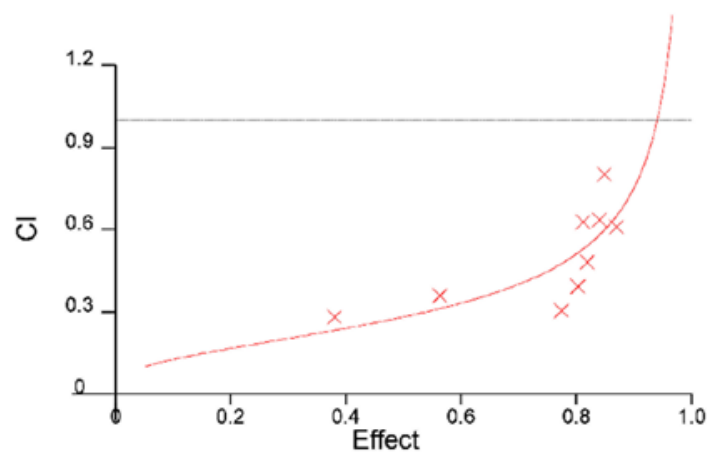

XATO+vismodegib

$\mathrm{Cl}=1.0$

Figure 6. Combination of Hedgehog inhibitors and standard chemotherapeutic reagents induces synergistic inhibition of the viability of human osteosarcoma cells. Saos 2 cells were cultured in the presence of ATO, CDDP, IFO, DOX, and vismodegib or in combination. Cell viability was measured by WST-1 assays. Cell viability was measured by MTT after 48-h exposure. Combination-index and fractions affected were plotted in combination with ATO and CDDP, IFO, DOX, or vismodegib. 
Table I. Combination index (CI) for chemotherapy drugs.

A, 143B

\begin{tabular}{lcccc}
\hline Drugs & $\mathrm{CI} \mathrm{ED}_{50}$ & $\mathrm{CI} \mathrm{ED}_{75}$ & $\mathrm{CI} \mathrm{ED}_{90}$ & $\mathrm{CI} \mathrm{ED}_{50-90}$ \\
\hline $\begin{array}{l}\text { ATO + CDDP } \\
(\mathrm{CR} ; 1: 4)\end{array}$ & 0.52 & 0.39 & 0.32 & 0.41 \\
$\begin{array}{l}\mathrm{ATO}+\mathrm{IFO} \\
(\mathrm{CR} ; 1: 5,000)\end{array}$ & 0.79 & 0.59 & 0.47 & 0.61 \\
$\begin{array}{l}\text { ATO + DOX } \\
(\mathrm{CR} ; 5: 1)\end{array}$ & 1.13 & 0.80 & 0.60 & 0.84 \\
$\begin{array}{l}\text { ATO + Vis } \\
(\mathrm{CR}: 1: 200)\end{array}$ & 0.22 & 0.39 & 0.69 & 0.43 \\
\hline
\end{tabular}

$\mathrm{B}, \mathrm{SaOs} 2$

\begin{tabular}{lcccc}
\hline Drugs & $\mathrm{CI} \mathrm{ED}_{50}$ & $\mathrm{CI} \mathrm{ED}_{75}$ & $\mathrm{CI} \mathrm{ED}_{90}$ & $\mathrm{CI} \mathrm{ED}_{50-90}$ \\
\hline $\begin{array}{l}\mathrm{ATO}+\mathrm{CDDP} \\
(\mathrm{CR} ; 1: 4)\end{array}$ & 0.89 & 0.70 & 0.66 & 0.75 \\
$\begin{array}{l}\mathrm{ATO}+\mathrm{IFO} \\
(\mathrm{CR} ; 1: 5,000)\end{array}$ & 0.89 & 0.69 & 0.56 & 0.71 \\
$\begin{array}{l}\text { ATO + DOX } \\
(\mathrm{CR} ; 5: 1)\end{array}$ & 1.06 & 0.67 & 0.44 & 0.72 \\
$\begin{array}{l}\text { ATO + Vis } \\
(\mathrm{CR}: 1: 200)\end{array}$ & 0.28 & 0.45 & 0.75 & 0.49 \\
\hline
\end{tabular}

$\mathrm{ED}_{50-90}$ (the average $\mathrm{CI}$ at $\mathrm{ED}_{50}$ to $\mathrm{ED}_{90}$ ) of $143 \mathrm{~B}$ cells were 0.41 , 061, and 0.84, respectively (Table IA). CIs of ATO and CDDP, IFO, or DOX for $\mathrm{ED}_{50-90}$ of Saos 2 were $0.75,0.71$, and 0.72 , respectively (Table IB). Synergistic effects were observed for all concentrations except for combination of DOX at the $\mathrm{ED}_{50}$ in $143 \mathrm{~B}$ and Saos 2 cells. Next, we examined the combination effects of Hedgehog inhibitors using ATO and vismodegib. Synergic effects were observed at $\mathrm{ED}_{50}$ to $\mathrm{ED}_{90}$ of $143 \mathrm{~B}$ and Saos 2 cells (Table I). These findings suggest that combination of Hedgehog inhibitors and standard chemotherapeutic reagents prevent osteosarcoma cell proliferation synergistically.

Combination therapy of Hedgehog pathway inhibitors and standard chemotherapeutic reagents in osteosarcoma cells in vivo. Nude mice were inoculated with 143B osteosarcoma cells. ATO, IFO, CDDP, or vismodegib were intraperitoneally administered, as previously reported $(11,15,20)$. Because intraperitoneal DOX treatment induces severe peritonitis, intravenous administration of DOX is recommended (20). Our preliminary experiment showed intravenous treatment could not achieve reproducibility because of vascular leak and vascular occlusion. Compared with vehicle treatment, treatment with ATO and CDDP or IFO significantly prevented tumor growth (Fig. 7A and B). Next, we examined the combined effect of Hedgehog inhibitors, ATO and vismo-
A

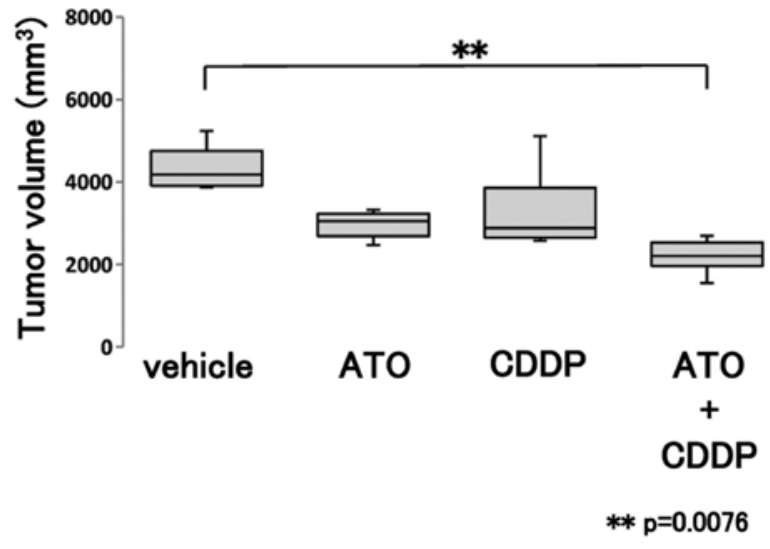

B

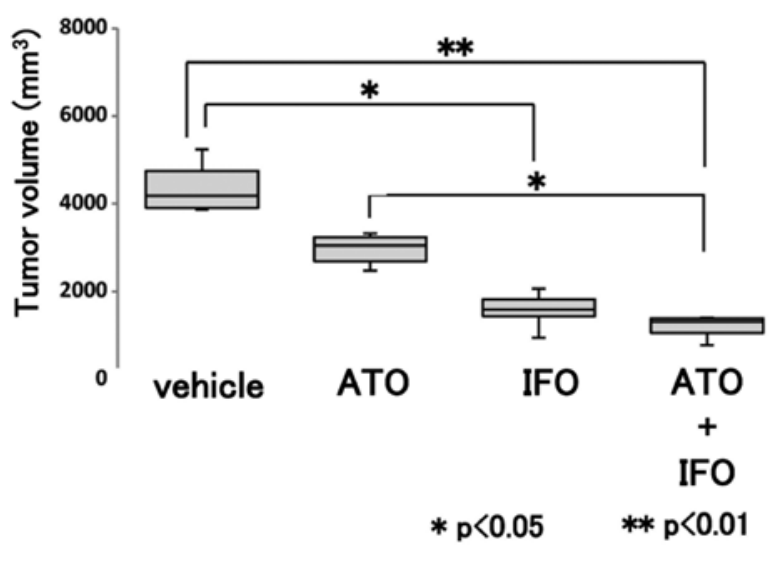

C

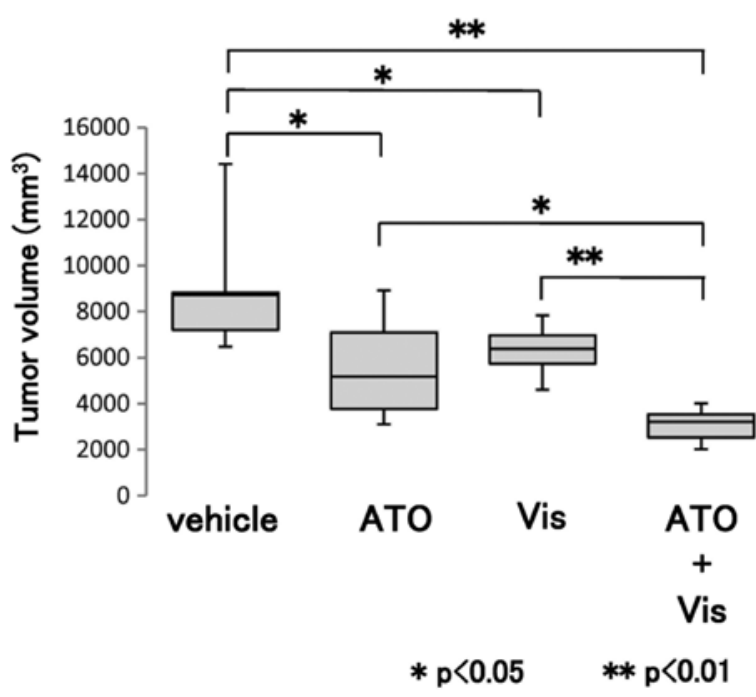

Figure 7. Combination of Hedgehog inhibitors and standard chemotherapeutic reagents induces synergistic inhibition of human osteosarcoma growth in vivo. Stably GFP-expressing 143B cells were inoculated subcutaneously or into the left knee joint of nude mice ( $\mathrm{n}=8$ or 9 per group). Tumor volume was calculated weekly using the formula $\mathrm{LW}^{2} / 2$ (where $\mathrm{L}$ and $\mathrm{W}$ represent the length and width of tumors). Seven days following inoculation, tumor volume was set as 1 , and the tumor volume was evaluated at different time-points. Treatment with ATO and CDDP, IFO, or vismodegib prevented osteosarcoma growth in vivo. ${ }^{*} \mathrm{P}<0.05,{ }^{* *} \mathrm{P}<0.01$, Kruskal-Wallis test.

degib. Compared with the vehicle control, ATO, or vismodegib treatment, combination of ATO and vismodegib significantly prevented tumor growth (Fig. 7C). These findings suggest that the combined administration of ATO and standard chemo- 
therapeutic reagents might be effective in the treatment of osteosarcoma.

\section{Discussion}

Aberrant activation of the Hedgehog pathway due to mutations of regulatory components or without driver mutations have been reported in many malignancies (21-28). Although treatment with vismodegib substantially benefited patients with advanced basal cell carcinoma (29), there have been disappointing reports for vismodegib from trials in colorectal and ovarian cancers $(30,31)$ and clinical trials of saridegib (a SMO inhibitor) were halted because of failures in pancreatic cancer, myelofibrosis and chondrosarcoma (28). In addition, mutations in SMO and Sufu heterozygous mice have been shown to be unresponsive to SMO inhibitors $(28,32)$. Non-Hedgehog pathway-mediated activation of GLI transcription has been also reported (28). These findings suggest that additional approaches should be considered for Hedgehog inhibition therapy for malignancy. Accordingly, ATO, which inhibits GLI transcription, may be a more effective Hedgehog targeting agent.

We and others reported that SMO and GLI2 were overexpressed in human osteosarcoma specimens $(8,9,12)$. Upregulated expression levels of GLI2 correlated with lung metastasis and poor survival of osteosarcoma patients $(11,12)$. Inhibition of GLI2 or SMO prevents osteosarcoma growth both in vitro and in vivo $(8,9)$. ATO inhibits the activation of Hedgehog signaling and promotes apoptotic cell death in osteosarcoma cells (15). We used ATO at $10 \mathrm{mg} / \mathrm{kg}$ body weight intraperitoneally, as previously reported (33). However, the concentration of ATO used in vivo was two-fold greater than that used for human APL therapy (34). To decrease the ATO concentration, combinations of Hedgehog inhibitors and standard anticancer drugs were examined. Our findings showed that combined treatment of ATO with CDDP, IFO, or DOX prevents osteosarcoma proliferation synergistically in vitro. In vivo examinations showed that statistical differences in tumor size were observed between the vehicle and combinations of ATO with CDDP or ATO with IFO. These findings suggest that combination therapy might decrease the effective concentration of each drug. The lower levels of reagents that could be used in these combinations might reduce toxicities associated with effective use of a single drug.

Kim et al reported that combined use of ATO and itraconazole, a SMO inhibitor, enables a reduced dose of ATO and itraconazol to prevent medulloblastoma and basal cell carcinoma growth (35). Consistent with this report, we showed that combined use of ATO with vismodegib permits a reduced dose of both ATO and vismodegib, and inhibited osteosarcoma growth synergistically in vitro and in vivo. Although the majority of side effects of vismodegib are not so severe, $>50 \%$ of patients discontinued their drug treatment because of side effect concerns for long-term compliance $(16,36)$. Combination of ATO with vismodegib might decrease the effective concentration of each drug. The lower levels of reagents that could be used in these combinations might reduce toxicity.

Because osteosarcoma is an extremely heterogeneous and genomically unstable tumor (37), preselection of osteosarcoma patients with activated Hedgehog is required before treatment with Hedgehog inhibitors. Shou et al developed a five-gene Hedgehog signature for patient preselection for Hedgehog inhibitor therapy in medulloblastoma (38). This method might be useful for other Hedgehog-activated malignancies including osteosarcoma.

There is a possibility that the pleotropic effect of ATO and off-target effects of SMO might affect the growth inhibition of osteosarcoma. Nonetheless, combinations of ATO with vismodegib or standard anticancer reagents showed promising therapeutic efficacy for osteosarcoma.

Taken together, these findings indicate that combination of Hedgehog pathway inhibitors and standard FDA-approved anticancer agents with established safety profiles for human use may be an attractive therapeutic method for treating osteosarcoma.

\section{Acknowledgements}

We are grateful to Hui Gao for her excellent technical assistance. We wish to thank the joint research laboratory of Kagoshima University Graduate School of Medical and Dental Sciences. This study was supported by Grantsin-Aid for Scientific Research (KAKENHI) (C) 19591725, (C) 20591786, (C) 21591919, (C) 21591920, (C) 22591663, and (C) 23592195, a Grant-in-Aid from the Ministry of Health, Labour and Welfare of Japan for the Third Term Comprehensive Control Research for Cancer, and Scientific Research on Priority Areas 201201976 to H. Nagao from the Grants-in-Aid for JSPS Fellows. We thank for Edanz Group Japan for English Editing service.

\section{References}

1. Sweetnam R: Osteosarcoma. Br J Hosp Med 28: 112, 116-121, 1982.

2. Dorfman HD and Czerniak B: Bone cancers. Cancer 75 (Suppl): 203-210, 1995.

3. Hegyi M, Semsei AF, Jakab Z, Antal I, Kiss J, Szendroi M, Csoka M and Kovacs G: Good prognosis of localized osteosarcoma in young patients treated with limb-salvage surgery and chemotherapy. Pediatr Blood Cancer 57: 415-422, 2011.

4. He JP, Hao Y, Wang XL, Yang XJ, Shao JF, Guo FJ and Feng JX: Review of the molecular pathogenesis of osteosarcoma. Asian Pac J Cancer Prev 15: 5967-5976, 2014.

5. Nybakken K and Perrimon N: Hedgehog signal transduction: Recent findings. Curr Opin Genet Dev 12: 503-511, 2002.

6. Petrova R and Joyner AL: Roles for Hedgehog signaling in adult organ homeostasis and repair. Development 141: 3445-3457, 2014.

7. Briscoe $\mathrm{J}$ and Thérond PP: The mechanisms of Hedgehog signalling and its roles in development and disease. Nat Rev Mol Cell Biol 14: 416-429, 2013.

8. Hirotsu M, Setoguchi T, Sasaki H, Matsunoshita Y, Gao H, Nagao H, Kunigou O and Komiya S: Smoothened as a new therapeutic target for human osteosarcoma. Mol Cancer 9: 5, 2010.

9. Nagao H, Ijiri K, Hirotsu M, Ishidou Y, Yamamoto T, Nagano S, Takizawa T, Nakashima K, Komiya S and Setoguchi T: Role of GLI2 in the growth of human osteosarcoma. J Pathol 224: 169-179, 2011.

10. Nagao-Kitamoto H, Setoguchi T, Kitamoto S, Nakamura S, Tsuru A, Nagata M, Nagano S, Ishidou Y, Yokouchi M, Kitajima S, et al: Ribosomal protein S3 regulates GLI2-mediated osteosarcoma invasion. Cancer Lett 356B: 855-861, 2015.

11. Nagao-Kitamoto H, Nagata M, Nagano S, et al: GLI2 is a novel therapeutic target for metastasis of osteosarcoma. Int $\mathbf{J}$ Cancer 136: 1276-1284, 2015.

12. Yang W, Liu X, Choy E, Mankin H, Hornicek FJ and Duan Z: Targeting hedgehog-GLI-2 pathway in osteosarcoma. J Orthop Res 31: 502-509, 2013 
13. Nasr R, Guillemin MC, Ferhi O, Soilihi H, Peres L, Berthier C, Rousselot P, Robledo-Sarmiento M, Lallemand-Breitenbach V, Gourmel B, et al: Eradication of acute promyelocytic leukemiainitiating cells through PML-RARA degradation. Nat Med 14: 1333-1342, 2008.

14. Beauchamp EM, Ringer L, Bulut G, Sajwan KP, Hall MD, Lee YC, Peaceman D, Ozdemirli M, Rodriguez O, Macdonald TJ, et al: Arsenic trioxide inhibits human cancer cell growth and tumor development in mice by blocking Hedgehog/GLI pathway. J Clin Invest 121: 148-160, 2011.

15. Nakamura S, Nagano S, Nagao H, Ishidou Y, Yokouchi M, Abematsu M, Yamamoto T, Komiya S and Setoguchi T: Arsenic trioxide prevents osteosarcoma growth by inhibition of GLI transcription via DNA damage accumulation. PLoS One 8: e69466, 2013.

16. Sekulic A, Migden MR, Oro AE, Dirix L, Lewis KD, Hainsworth JD, Solomon JA, Yoo S, Arron ST, Friedlander PA et al: Efficacy and safety of vismodegib in advanced basal-cell carcinoma. N Engl J Med 366: 2171-2179, 2012.

17. Chou TC and Talalay P: Quantitative analysis of dose-effect relationships: The combined effects of multiple drugs or enzyme inhibitors. Adv Enzyme Regul 22: 27-55, 1984

18. Iwamoto $\mathrm{Y}$ and Tanaka K: The activity of the Bone and Soft Tissue Tumor Study Group of the Japan Clinical Oncology Group. Jpn J Clin Oncol 42: 467-470, 2012.

19. Keating GM: Vismodegib: In locally advanced or metastatic basal cell carcinoma. Drugs 72: 1535-1541, 2012.

20. Budach W, Budach V, Stuschke M, Schmauder B, Reipke P and Scheulen ME: Efficacy of ifosfamide, dacarbazine, doxorubicin and cisplatin in human sarcoma xenografts. Br J Cancer 70 : 29-34, 1994.

21. Gailani MR, Ståhle-Bäckdahl M, Leffell DJ, Glynn M, Zaphiropoulos PG, Pressman C, Undén AB, Dean M, Brash DE, Bale AE, et al: The role of the human homologue of Drosophila patched in sporadic basal cell carcinomas. Nat Genet 14: 78-81, 1996.

22. Xie J, Murone M, Luoh SM, Ryan A, Gu Q, Zhang C, Bonifas JM, Lam CW, Hynes M, Goddard A, et al: Activating smoothened mutations in sporadic basal-cell carcinoma. Nature 391: 90-92, 1998.

23. Slade I, Murray A, Hanks S, Kumar A, Walker L, Hargrave D, Douglas J, Stiller C, Izatt L and Rahman N: Heterogeneity of familial medulloblastoma and contribution of germline PTCH1 and SUFU mutations to sporadic medulloblastoma. Fam Cancer 10: 337-342, 2011

24. Raffel C, Jenkins RB, Frederick L, Hebrink D, Alderete B, Fults DW and James CD: Sporadic medulloblastomas contain PTCH mutations. Cancer Res 57: 842-845, 1997.

25. Reifenberger J, Wolter M, Weber RG, Megahed M, Ruzicka T, Lichter P and Reifenberger G: Missense mutations in $\mathrm{SMOH}$ in sporadic basal cell carcinomas of the skin and primitive neuroectodermal tumors of the central nervous system. Cancer Res 58 : $1798-1803,1998$

26. Taylor MD, Liu L, Raffel C, Hui CC, Mainprize TG, Zhang X, Agatep R, Chiappa S, Gao L, Lowrance A, et al: Mutations in SUFU predispose to medulloblastoma. Nat Genet 31: 306-310, 2002.
27. Scales SJ and de Sauvage FJ: Mechanisms of Hedgehog pathway activation in cancer and implications for therapy. Trends Pharmacol Sci 30: 303-312, 2009.

28. Amakye D, Jagani Z and Dorsch M: Unraveling the therapeutic potential of the Hedgehog pathway in cancer. Nat Med 19 1410-1422, 2013

29. Basset-Seguin N, Hauschild A, Grob JJ, Kunstfeld R, Dréno B, Mortier L, Ascierto PA, Licitra L, Dutriaux C, Thomas L, et al: Vismodegib in patients with advanced basal cell carcinoma (STEVIE): A pre-planned interim analysis of an international, open-label trial. Lancet Oncol 16: 729-736, 2015.

30. Berlin J, Bendell JC, Hart LL, Firdaus I, Gore I, Hermann RC, Mulcahy MF, Zalupski MM, Mackey HM, Yauch RL, et al: A randomized phase II trial of vismodegib versus placebo with FOLFOX or FOLFIRI and bevacizumab in patients with previously untreated metastatic colorectal cancer. Clin Cancer Res 19: 258-267, 2013.

31. Kaye SB, Fehrenbacher L, Holloway R, Amit A, Karlan B, Slomovitz B, Sabbatini P, Fu L, Yauch RL, Chang I, et al: A phase II, randomized, placebo-controlled study of vismodegib as maintenance therapy in patients with ovarian cancer in second or third complete remission. Clin Cancer Res 18: 65096518,2012

32. Lee Y, Kawagoe R, Sasai K, Li Y, Russell HR, Curran T and McKinnon PJ: Loss of suppressor-of-fused function promotes tumorigenesis. Oncogene 26: 6442-6447, 2007.

33. Kim J, Lee JJ, Kim J, Gardner D and Beachy PA: Arsenic antagonizes the Hedgehog pathway by preventing ciliary accumulation and reducing stability of the Gli2 transcriptional effector. Proc Natl Acad Sci USA 107: 13432-13437, 2010.

34. Shen ZX, Chen GQ, Ni JH, Li XS, Xiong SM, Qiu QY, Zhu J, Tang W, Sun GL, Yang KQ, et al: Use of arsenic trioxide $\left(\mathrm{As}_{2} \mathrm{O}_{3}\right)$ in the treatment of acute promyelocytic leukemia (APL): II. Clinical efficacy and pharmacokinetics in relapsed patients. Blood 89: 3354-3360, 1997.

35. Kim J, Aftab BT, Tang JY, Kim D, Lee AH, Rezaee M, Kim J, Chen B, King EM, Borodovsky A, et al: Itraconazole and arsenic trioxide inhibit Hedgehog pathway activation and tumor growth associated with acquired resistance to smoothened antagonists. Cancer Cell 23: 23-34, 2013.

36. Tang JY, Mackay-Wiggan JM, Aszterbaum M, Yauch RL, Lindgren J, Chang K, Coppola C, Chanana AM, Marji J, Bickers DR, et al: Inhibiting the hedgehog pathway in patients with the basal-cell nevus syndrome. N Engl J Med 366: 2180-2188, 2012

37. Kuijjer ML, Hogendoorn PC and Cleton-Jansen AM: Genomewide analyses on high-grade osteosarcoma: making sense of a genomically most unstable tumor. Int J Cancer 133: 2512-2521, 2013.

38. Shou Y, Robinson DM, Amakye DD, Rose KL, Cho YJ, Ligon KL, Sharp T, Haider AS, Bandaru R, Ando Y, et al: A five-gene hedgehog signature developed as a patient preselection tool for hedgehog inhibitor therapy in medulloblastoma. Clin Cancer Res 21: 585-593, 2015. 